\title{
Thermal Management for Heavy Vehicles (Class 7-8 Trucks)
}

\author{
Workshop Report and Multiyear Program Plan
}

\author{
Prepared for
}

U.S. Department of Energy

Energy Efficiency and Renewable Energy

Office of Transportation Technologies

Office of Heavy Vehicle Technologies

\section{by}

\author{
Martin W. Wambsganss \\ Energy Technology Division \\ Argonne National Laboratory \\ 9700 S. Cass Avenue \\ Argonne, IL 60439
}

January 2000 


\section{Contents}

$\begin{array}{ll}\text { Executive Summary } & 1\end{array}$

1 Background and Introduction $\quad 4$

2 Summary of Workshop Presentations $\quad 8$

2.1 Heavy-Duty Diesel-Engine Manufacturer 8

2.2 Class 7-8 Truck Manufacturer 9

2.3 Equipment Suppliers 9

3 Recommendations for Future R\&D $\quad 11$

$\begin{array}{lll}3.1 & \text { Industry } & 12\end{array}$

3.2 Government (DOE/OHVT) 14

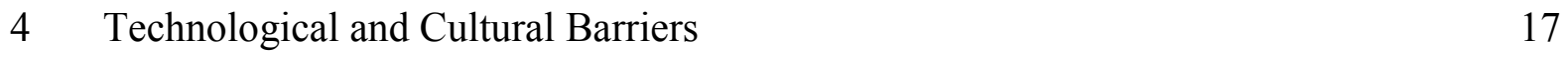

5 Multiyear Program Plan 19

$\begin{array}{lll}5.1 & \text { Task Descriptions } & 19\end{array}$

$\begin{array}{ll}5.2 \text { Duration/Budget } & 24\end{array}$

$\begin{array}{ll}\text { Acknowledgments } & 24\end{array}$

$\begin{array}{ll}\text { References } & 25\end{array}$

$\begin{array}{ll}\text { Appendices } & 26\end{array}$

$\begin{array}{ll}\text { A Workshop Agenda } & 26\end{array}$

B Workshop Participants 29

C Breakout Session Summaries $\quad 36$ 


\section{Tables}

1 DOE/OHVT Resource Requirements (\$1000) for Heavy-Duty Thermal Management Project Tasks

\section{Figures}

1 Office of Heavy Vehicle Technologies Program Coordination Structure 


\section{Executive Summary}

Thermal management is a crosscutting technology that has an important effect on fuel economy and emissions, as well as on reliability and safety, of heavy-duty trucks. Trends toward higherhorsepower engines, along with new technologies for reducing emissions, are substantially increasing heat-rejection requirements. For example, exhaust gas recirculation (EGR), which is probably the most popular near-term strategy for reducing $\mathrm{NO}_{\mathrm{x}}$ emissions, is expected to add 20 to $50 \%$ to coolant heat-rejection requirements. There is also a need to package more cooling in a smaller space without increasing costs. These new demands have created a need for new and innovative technologies and concepts that will require research and development, which, due to its long-term and high-risk nature, would benefit from government funding.

This document outlines a research program that was recommended by representatives of truck manufacturers, engine manufacturers, equipment suppliers, universities, and national laboratories. Their input was obtained through personal interviews and a plenary workshop that was sponsored by the DOE Office of Heavy Vehicle Technologies and held at Argonne National Laboratory on October 19-20, 1999.

Major research areas that received a strong endorsement by industry and that are appropriate for government funding were identified and included in the following six tasks:

- Program Management/Coordination and Benefits/Cost Analyses. It is imperative that truck and engine manufacturers and equipment suppliers work together to achieve the goal of an advanced thermal management system that is computercontrolled and more efficient, smaller in size, and lighter in weight than current systems. To ensure industry relevance, it is recommended that a working group be formed to assist DOE/OHVT in vectoring its thermal management research and development program, consistent with DOE/OHVT's mission statement. Thorough and credible benefits/cost analyses are also recommended to quantify the energysavings and emissions-reduction potential of new technologies. Such analyses will justify government support of the development of new technologies and will ultimately facilitate their adoption by industry. Several potentially energy-saving technologies that have been shown to be effective have not been adopted because there is insufficient information to demonstrate that the costs of implementation can be justified by the benefits.

- Advanced-Concept Development. There is a need for new and innovative advanced concepts. Those recommended for evaluation and, as judged appropriate, development and demonstration, include 
- Controlled nucleate-boiling cooling.

- Waste-heat-recovery/utilization technologies.

- Heat-pipe technology.

- Advanced Heat Exchangers and Heat-Transfer Fluids. Advanced heat exchangers that are compact and lightweight are needed. To achieve this goal, developments in the following areas are recommended:

- Innovative, enhanced airside heat-rejection concepts.

- New materials, such as carbon foams, for cooling-system components.

- Nanofluid technology for improving heat-transfer characteristics of coolants and engine oils.

- Fundamental understanding of fouling mechanisms and mitigation.

- Simulation-Code Development. A comprehensive computer code is needed to optimize future designs and to predict fuel economy and emissions for an entire drive cycle. This code would use modules for the power train, vehicle-load prediction, control systems, cooling systems, external aerodynamics, underhood airflow, cooling and refrigeration, lubricant cooling, and cabin airflow. Toward that end, development of a framework for the comprehensive code, a computational-fluid-dynamics module for underhood airflow and temperatures, interface specifications, and an experimental data base is recommended. Such a code would help to establish the benefits of new technologies. Also recommended is development of a simple system code to run on a $\mathrm{PC}$ for evaluating initial design concepts.

- Sensors and Control Components Development. The application of an advanced computer-controlled thermal-management system will require accurate, reliable, and robust real-time sensors for engine temperatures, pressures, coolant flow, and airflow, as well as $\mathrm{NO}_{\mathrm{x}}$ emissions. Such sensors would be used for computer control and feedback. Research needs in sensors and control components should be identified, and such components should be developed as needed.

- Concept/Demonstration Truck Sponsorship. The most convincing way to determine and demonstrate the benefits and costs of new technologies as they function within the entire system would be to incorporate them into a specially designed concept truck. Detailed drive-cycle data, including temperatures, pressures, and flow rates, as well as fuel economy and emissions, are required and can be obtained only from on-highway field testing with an instrumented truck. Detailed field data are also required for the validation and refinement of simulation codes. 
Sponsorship, with significant industry cost-sharing, of a concept/demonstration truck is strongly recommended.

An initial five-year program plan, with total DOE/OHVT funding of approximately $\$ 23$ million, is proposed in Table 1. It is expected that DOE/OHVT funding will be leveraged by industrial cost-sharing.

While the emphasis of the workshop, and of this workshop report and multiyear program plan, is on on-highway, heavy-duty (Class 7-8) trucks, the proposed multiyear research plan should be generally applicable to the bus, off-highway, and rail segments of the heavy-vehicle industry as well.

\section{Table 1. DOE/OHVT Resource Requirements (\$1000) for Heavy-Duty Thermal Management Project Tasks}

\begin{tabular}{|c|c|c|c|c|c|c|c|}
\hline Task & Task Descriptor & FY00 & FY01 & FY02 & FY03 & FY04 & FY05 \\
\hline 1 & $\begin{array}{l}\text { Program Management/Coordination } \\
\text { and Benefits/Cost Analyses }\end{array}$ & 50 & 350 & 350 & 250 & 250 & 250 \\
\hline 2 & Advanced-Concept Development & 50 & 500 & 800 & 850 & 850 & 850 \\
\hline 3 & $\begin{array}{l}\text { Advanced Heat Exchangers and Heat- } \\
\text { Transfer Fluids }\end{array}$ & 75 & 600 & 1000 & 1000 & 900 & 900 \\
\hline 4 & Simulation-Code Development & - & 500 & 800 & 1000 & 1100 & 1000 \\
\hline 5 & $\begin{array}{l}\text { Sensors and Control Components } \\
\text { Development }\end{array}$ & - & 150 & 350 & 500 & 500 & 400 \\
\hline 6 & $\begin{array}{l}\text { Concept/Demonstration Truck } \\
\text { Sponsorship }\end{array}$ & - & 225 & 900 & 1500 & 2250 & 2400 \\
\hline & Total & $175^{*}$ & 2325 & 4200 & 5100 & 5850 & 5800 \\
\hline
\end{tabular}

*Actual 


\section{Background and Introduction}

The U.S. Department of Energy (DOE) Office of Transportation Technologies (OTT) is part of the DOE's Office of Energy Efficiency and Renewable Energy. OTT works in partnership with the domestic transportation industry, energy supply industry, and research and development organizations to develop and promote user acceptance of advanced transportation vehicles and alternative fuel technologies. OTT's goals are to reduce oil import requirements, criteria pollutant emissions, and greenhouse gases. OTT also aims to develop a strong transportation technology base to ensure strong industry competition in domestic and world markets.

Within OTT, there are four areas of research and development: Office of Advanced Automotive Technologies, Office of Fuels Development, Office of Technology Utilization, and Office of Heavy Vehicle Technologies (OHVT). The program coordination structure of OHVT is given in Fig. 1.

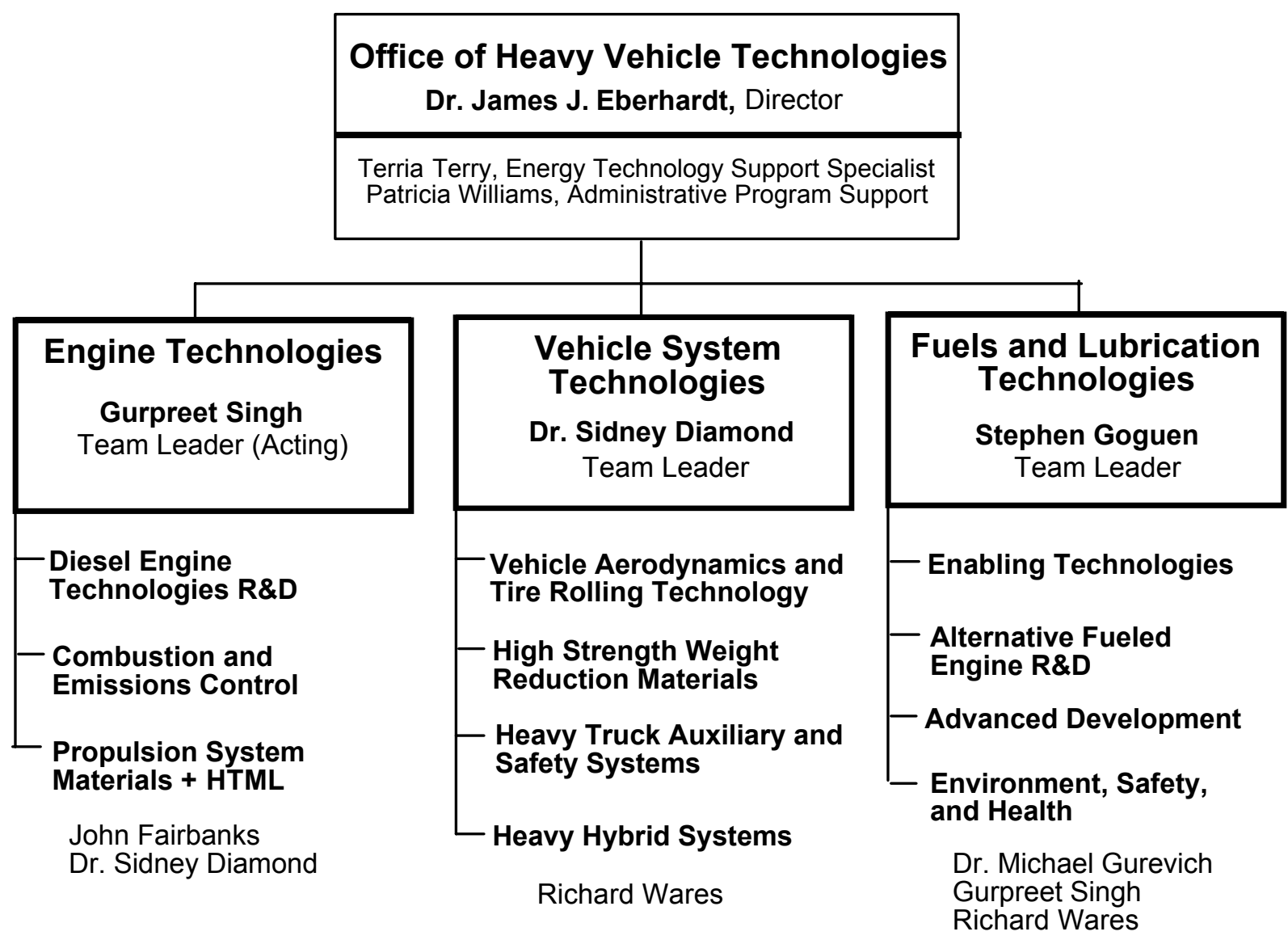

Fig. 1. Office of Heavy Vehicle Technologies Program Coordination Structure 
The very large and growing number of on-highway trucks has a major nationwide impact on fuel consumption and emissions production. The goals of OHVT are to improve fuel economy and reduce emissions of on-highway, heavy-duty diesel-powered trucks. With industry input, DOE/OHVT has developed a Technology Roadmap for Heavy Vehicles [1]. This roadmap formulates the goals, assesses the status of the technology, identifies technical targets and barriers to achieving those targets, develops an approach to overcoming the barriers, and determines schedules and milestones. The roadmap serves as the foundation for the DOE/OHVT multiyear program plan [2] that guides its sponsored research and development. In the Vehicles System Technologies area, illustrated in Fig. 2, DOE/OHVT has conducted workshops on aerodynamic drag, friction and wear, and rolling resistance and braking. The objective of these workshops was to obtain industry's input to OHVT's multiyear program plan in these topical areas. The workshops provide a unique opportunity for various segments of industry to assist in setting the DOE/OHVT research agenda on a national scale.
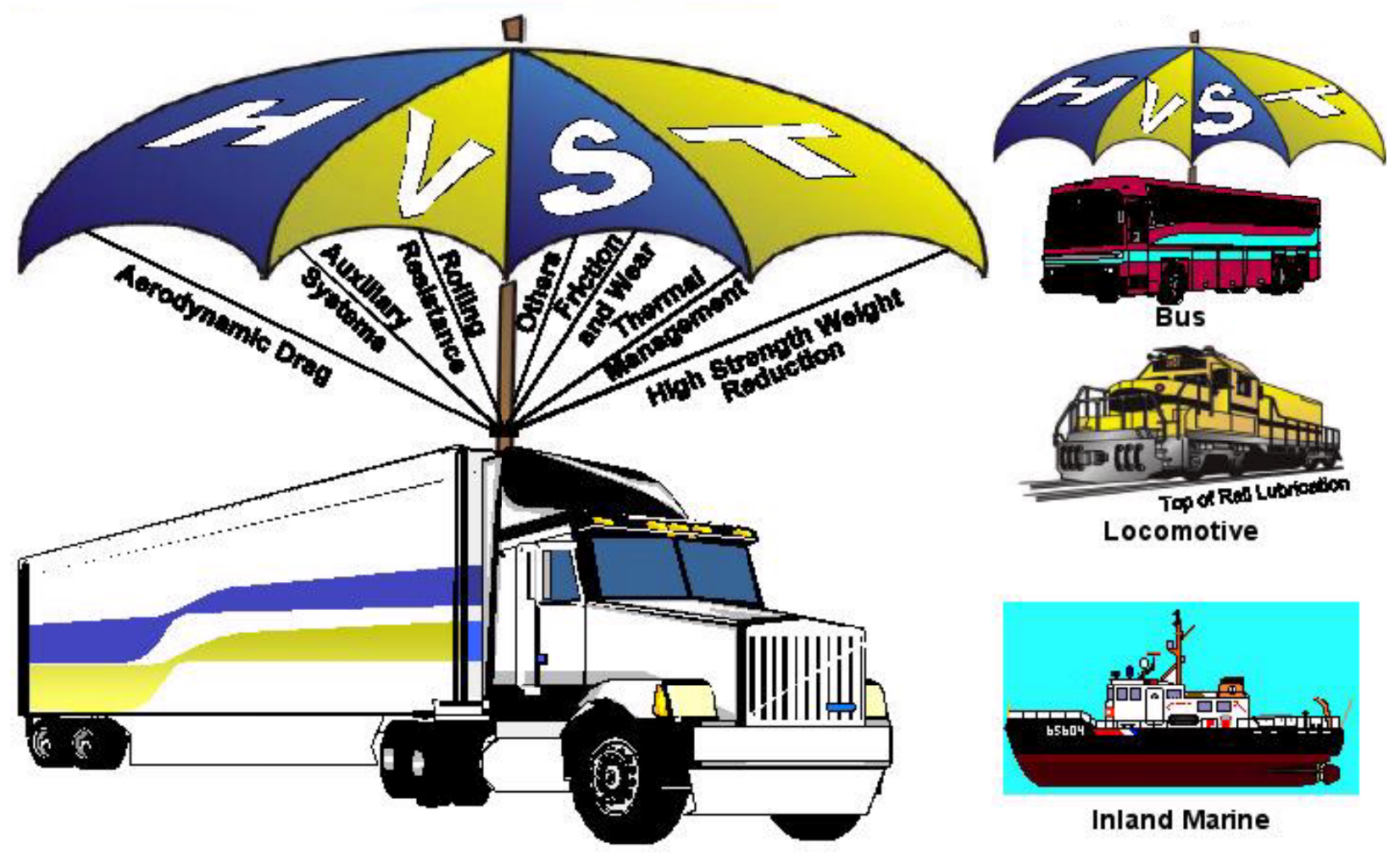

Inland Marine

Fig. 2. Heavy Vehicle Technologies 
Trends and performance objectives in the large-truck industry include higher-horsepower engines, improved engine performance, reduced aerodynamic drag, improved fuel economy, reduced emissions, improved safety, increased use of electronic devices, improved driver comfort, increased cargo-carrying capacity, higher reliability, reduced maintenance, and improved safety. Thermal management is a cross-cutting technology that directly or indirectly affects (or is affected by) all of the above. For example, because of the need to accommodate exhaust gas recirculation (EGR) cooling and because of trends toward more powerful engines, larger sleeper cabs (requiring more air conditioning), and additional auxiliary equipment, the heavy truck industry is facing substantial increases in heat rejection requirements. From a safety standpoint, there is a desire to reduce the size of the radiator to lower hood lines and improve driver visibility. This, in turn, would reduce aerodynamic drag and thus improve fuel economy. Complicating all of these changes and needs is that many conventional cooling system components are already at, or are approaching, their maximum practical size and functional limits.

The need to meet accelerated 2002 EPA standards for $\mathrm{NO}_{\mathrm{x}}$ reduction [3] has focused attention on the truck thermal-management system. This is because near-term emissions-control strategy involves EGR, and the need to provide EGR cooling can be expected to add 20 to $50 \%$ to the coolant heat rejection requirements. The large-truck industry's desire to go to higherhorsepower engines only exacerbates an already difficult situation. It has been an industry goal to keep the heat exchanger package from growing due to increased heat rejection demands. However, with the additional heat load of EGR cooling, this will be an unavoidable challenge. Keeping the heat exchanger package from growing can realistically be accomplished only by developing new technologies, e.g., innovative techniques to improve airside heat transfer, and/or new thermal management concepts. New concepts, on the other hand, can be expected to lead to an increase in system complexity, with a concurrent increase in cost for components, production, and service.

Thermal management is a systems technology with far-reaching effects. The trucking industry and its component suppliers are well aware of the broad implications of thermal management and continue to improve component and system designs. Nevertheless, there is a need for new and innovative technologies and concepts whose development is appropriate for government funding. While improved fuel economy is of interest to fleet operators, it is not their top priority, especially if it is achieved at the expense of higher capital cost for the truck. Similarly, emissions reduction becomes a high-priority item only when government regulations require it. On the other hand, fuel economy and emissions reduction are both high-priority objectives of the DOE.

The consensus of the trucking industry (both end-users and equipment suppliers) is that the time is right for assessing the state of the art in thermal management for large trucks and for 
the development and application of new and innovative technologies and advanced thermalmanagement-system concepts. Successful implementation of any new concept will require research and component development, together with close cooperation among equipment suppliers, engine manufacturers, truck manufacturers, and researchers. Barriers to the application of new technology include cost (both initial and life-cycle), complexity, and industry demand for high reliability and durability, and these account for much of the conservatism in the design of thermal management components. These barriers must be addressed and overcome.

A workshop on Thermal Management for Heavy Vehicles, with the objective to obtain industry input to the development of DOE/OHVT's multiyear program plan for thermal management in heavy vehicles, specifically Class 7-8 trucks, was sponsored by DOE/OHVT and held at Argonne National Laboratory on October 19-20, 1999. The workshop objective was accomplished by creating a forum for engine manufacturers, truck manufacturers, fleet operators, equipment suppliers, the DOE, national laboratories, universities, and research organizations, to

- Review performance objectives and future trends in the large-truck industry and their influence on thermal management.

- Review the state of the art, issues, and research needs relative to cooling methodologies, heat transfer fluids, equipment (heat exchangers, fans, pumps, actuators), materials, fabrication, modeling and simulation, underhood airflow, and aerodynamics.

- Assess the potential impact of improved truck thermal-management systems on energy savings, emissions reduction, and safety.

- Present advanced thermal-management concepts and designs and their benefits.

- Identify barriers to application of advanced concepts and designs.

- Establish and prioritize design goals and research needs.

In the workshop, a series of presentations by representatives from industry was followed by four technical breakout sessions; see the workshop agenda in Appendix A. The presentations were intended to provide background information and stimulate thinking for the breakout sessions. Research projects were identified and prioritized in the breakout sessions. A list of workshop participants is given in Appendix B.

In this report, (a) workshop presentations by representatives from an engine manufacturer, a truck manufacturer, and various equipment suppliers are summarized in 
Section 2, relative to OEM/customer needs, industry trends, and future R\&D requirements; (b) recommended research tasks, categorized as appropriate for industry or appropriate for DOE funding, are listed in Section 3; (c) barriers to the implementation of new technologies are discussed in Section 4; and (d) a multiyear plan for DOE-supported research is proposed in Section 5 .

The emphasis of the workshop, and of this workshop report and multiyear program plan, is on heavy-duty, on-highway (Class 7-8) trucks. Nevertheless, it is significant to note that many of the same challenges in thermal management are shared with the bus, off-highway, and rail industries. Therefore, the proposed multiyear research plan should be generally applicable to these segments of the heavy vehicle industry as well.

\section{Summary of Workshop Presentations}

As noted above, workshop speakers included representatives from an engine manufacturer, a truck manufacturer, and equipment suppliers (see Appendix A). These speakers reviewed the state of the art, trends, and future $R \& D$ requirements from the perspective of industry. In the following subsections, these presentations are summarized relative to industry/customer needs, trends, and future $R \& D$ requirements.

\subsection{Heavy-Duty Diesel-Engine Manufacturer}

From the customer standpoint, the target is to reduce owning and operating costs. From the national standpoint, the target is to reduce emissions. Thus, the overall goal is to improve fuel economy while reducing emissions.

Current customer needs, relative to the engine, are (a) improved reliability/durability, (b) improved fuel economy, (c) reduced maintenance, (d) improved serviceability, (e) improved productivity, (f) more diagnostics, (g) driver-friendliness, and (h) emissions compliance.

An idealized approach to engine and truck development would (a) combine multidimensional analysis with smart testing; (b) perform baseline tests to validate the analytical

tools; (c) apply the analysis tools to optimize and develop the engine, truck, and components in a virtual environment; and (d) perform a final validation test.

Future needs will include (a) deep integration of the engine, vehicle, and cooling system; (b) advanced, selectively cooled engines; (c) long-life, environmentally friendly coolants; (d) compact heat exchangers; (e) high-performance fans; and (f) sophisticated modeling tools. 


\subsection{Class 7-8 Truck Manufacturer}

The wants and needs of the customer, public, engine OEMs, and truck OEMs, are many and varied:

- Customers want higher-horsepower engines (the average now is $435 \mathrm{hp}$ and growing), improved driver visibility (lower hood profile), and aerodynamic styling.

- The public wants reduced emissions and less vehicle noise.

- Engine OEMs want (a) fuel-efficient engines, (b) durable engines (one million miles to engine overhaul), (c) cost-effective engines (low installed and maintenance costs).

- Truck OEMs want vehicles that are (a) stylish, fuel efficient, and quiet (b) durable (vehicle life $>1,250,000$ miles), and (c) cost-effective.

In general, there is a need to package more cooling in a smaller space without increasing the cost. This requires new technologies. The time, then, is right for new technology. If new technologies are not rapidly developed and implemented, and industry is thus forced to apply state-of the-art technology to accommodate the demand for increased cooling,

- Aerodynamic styling may be comprised.

- Fuel economy may not improve.

- Cooling fan noise may increase.

- Higher horsepower may not be available.

- Visibility may suffer.

- Engine performance, cost effectiveness, and/or durability may be compromised.

- Vehicle appearance may suffer, and costs of operation and maintenance may increase.

\subsection{Equipment Suppliers}

Heat-Transfer Fluids. There is a need for improved coolants with longer lives, improved heat-transfer characteristics, environmental friendliness, and lower disposal costs. In addition to absorbing and transferring heat, a heat-transfer fluid (coolant and/or engine oil) may 
also control friction and wear, transfer force, scavenge contaminants, and prevent corrosion. Many physical and chemical properties bear on these functions, and the relative importance of these properties depends on the specific hardware and application. Development of a fluid to meet a particular set of specifications, and the qualification of that fluid, can be a long and expensive process. Nevertheless, several unexplored possibilities for improving a fluid's heat transfer characteristics should be considered.

Heat Exchangers. For the foreseeable future, it is anticipated that heat exchangers will be made of aluminum and will remain in the front of the truck behind a grille, but that lower hood lines will force new shapes, concepts, and packaging styles. There will be more calculation/simulation and less engine/vehicle testing, leading to greater use of computational fluid dynamics (CFD) in design, for both component improvement and complete underhood thermal management.

Fans and Fan Drives. Future key issues relative to fan drives are torque capacity (need to handle a load in excess of $60 \mathrm{hp}$ ), variable-speed control, step-up ratios, and system integration; also important are maintenance issues related to radiator and cab air conditioning, charge-air cooling, and fouling. Alternate fan technologies must be considered in future designs because fan geometry is essentially fixed by the available space, fan speed is at or near maximum, and fan power cannot increase (because of fuel economy, fan-drive-system costs, and fan noise).

Coolant Pumps. Several trends related to diesel engines and truck design will increase the thermal load on the cooling system of the vehicle. With respect to the engine, these trends include later injection timing for $\mathrm{NO}_{\mathrm{x}}$ control, EGR, advanced turbochargers, exhaust-gas oxidation catalysts, longer maintenance intervals, and extended engine life. Vehicle trends include increased power; integrated electronic control systems; reduced frontal area; increased "hotel" loads; high-efficiency, lightweight components; liquid-cooled brakes; and liquid-cooled alternators.

In current systems, coolant flow and pressure are directly related to engine speed and thermostat setting. Also, cooling systems are sized for the maximum thermal load at high ambient temperatures. As a result, performance under typical conditions is less than optimal. There is a need for increased pump reliability/durability, higher efficiency, and variable-speed (electric) drives.

The advantages of an advanced cooling system based on a variable-speed coolant pump include constant and higher engine temperature, faster engine warm-up, smaller heat exchangers, improved fuel economy, reduced cooling fan operation, and faster cab heating. 
Cab Climate Control Systems. There is a need to improve driver comfort and ergonomics. This will contribute to driver retention, which, in turn, will enhance safety. System efficiencies must also be improved, focusing on, among other things, engine/chassis integration, controls, noise reduction, and insulation. In addition to incremental component and system improvements, quantum leaps also are required.

Transport Refrigeration. Demands for transport refrigeration can be expected to increase. The industry also must address related environmental issues. Alternatives to the vapor-compression refrigeration system should be evaluated, including Lorentz cycles, Stirling cycle, thermo-acoustic refrigeration, and thermoelectric refrigeration. Natural refrigerants such as carbon dioxide are already being evaluated.

Emissions Regulations and Engine Durability. Current and near-future exhaustemissions legislation for heavy-duty engines has been met by optimization of combustion systems, widespread use of turbocharging, aftercoolers, high-pressure fuel-injection equipment, and injection-timing retardation. Future legislation, including 2002 EPA regulations, will require additional emissions reduction technology such as EGR and/or exhaust-gas aftertreatment.

Relative to thermal loading, retarded injection timing increases overall heat rejection to coolant and oil by up to $10 \%$. Local thermal load at the top of the cylinder bore may increase by 30 to $80 \%$. EGR raises inlet manifold temperatures, increases the thermal load on the cooling system, and deprives the engine of coolant diverted to the EGR cooler.

Several approaches can be considered for improving thermal-management systems to cope with increased heat rejection and thermal loads. These include precision cooling; new and/or improved cooling strategies; reduced parasitic loads on the engine; optimized external coolant circuits; electric water and oil pumps; electronic thermostats and valves; improved radiators and fans; variable-speed fan drives; improved heat-transfer fluids; operation at higher coolant temperatures; and electrically driven air-conditioning compressors. All have varying influences across the ranges of vehicle speeds, engine speeds, and engine loads. As a consequence, we must be able to evaluate the benefits of design changes on vehicle fuel economy and emissions over the entire vehicle speed and load range; this requires a validated drive-cycle simulation code.

\section{Recommendations for Future R\&D}

After the workshop presentations, four breakout sessions, each facilitated by an industrial representative, were conducted. The topical areas for each of the four sessions were: 
- Session A: Engine Cooling Methodologies/System Architectures, ComputerControlled Systems.

- Session B: Heat Exchangers, Heat-Transfer Fluids, Heat-Transfer Enhancements, Climate Control, Refrigeration.

- Session C: Fans, Pumps, Actuators, Sensors, Waste-Heat Recovery/Utilization, Heat Storage, Brake Cooling, Auxiliary Power Units.

- Session D: Modeling, Simulation, Underhood Airflow, Aerodynamics.

In the breakout sessions, issues were discussed and research needs identified. Summaries of the discussion, as documented by the breakout session recorders, are included in Appendix C. Results from the discussions, coupled with information conveyed during the workshop presentations (see Section 2), were used to develop a list of recommended R\&D areas/projects.

In the following subsections, an attempt has been made to categorize these research areas/projects as being "most appropriate for industry" and "most appropriate for government funding." The criteria for a project to be categorized as "industry-appropriate" are that it is directly related to component development and/or is related to the application of existing technology. Criteria for "government (DOE) funding" are that the research long-range and/or high-risk, that it is demonstrates proof-of-concept, or would lead to development of technologies that are "enabling," i.e., technologies that would encourage the introduction of advanced components and concepts into wider acceptability and use. It is anticipated that individual companies can use these recommendations to define and focus their own research plans. The listing recommended for DOE funding will be used to define the DOE/OHVT multiyear research plan; the plan is presented in Section 5 of this report. No attempt has been made to prioritize either list.

\subsection{Industry}

Industry's focus is on improving existing equipment to meet requirements for added heat rejection. It is already conducting much of the research and development identified in the following listing of recommended research areas/projects.

\section{Component Development}

- Variable-speed fan drives.

- Noise control associated with large-diameter fans. 
- Variable-speed electric pumps.

- Electrically driven variable-speed compressors.

- Alternate fan types (radial, centrifugal, mixed flow, dual systems).

- More compact and lighter-weight heat exchangers.

- Shaped (e.g., curved) heat exchangers.

- EGR heat exchangers.

\section{System Design and Architectures}

- Heat exchanger "packaging," e.g., side-by-side and radiator-in-front-of-condenser.

- Compact cooling system based on radial fan.

- Separate cooling systems for EGR and engine.

- Heat exchanger package divorced from front of the truck and made smaller.

- Selective cooling.

- Control strategies/technologies.

\section{Sensors and Control Components Development}

- More reliable and accurate sensors.

- Electronic thermostat.

- Electronic flow control valves.

- Higher-capacity control module for integrated system control.

\section{Operating Specifications/Strategies}

- Implement anti-idling technologies and/or practices. 
- Increase allowable engine temperatures; increase maximum allowable coolant temperature exiting engine to about $260^{\circ} \mathrm{F}$ to increase $\Delta \mathrm{T}$.

\section{Fuels and Emissions}

- Lobby to change emission standard to $\mathrm{g} /$ mile basis.

- Develop fuel specifications for reduced emissions.

- Evaluate/develop non-EGR emissions reduction options.

\section{Culture}

- Need for component/equipment suppliers to work more closely with each other and with truck OEMs to address goals of improving thermal management systems.

- Optimize thermal-management-system designs; this may require removing certain options formerly available, but should benefit the customer in the long run; the customer needs to be educated.

- Facilitate system simulation with system-modeling data provided by suppliers, along with their subsystem component.

- Learn from the automobile industry.

- Educate fleet and individual-owner operators on the benefits of anti-idling.

\subsection{Government (DOE/OHVT)}

The research areas/projects listed below have been identified as appropriate for DOE/OHVT support/funding with industry cost-sharing. The focus of governmentsponsored/industry-cost-shared research is on proof-of-concept studies and tests, to be followed by developmental studies and demonstration, leading to ultimate commercialization by industry.

\section{Benefits/Cost Analyses}

- Perform analyses to quantify energy savings and emissions reduction that are possible from aggregated benefits directly or indirectly attributed to improved thermalmanagement systems. 
- Evaluate benefits and costs of introducing a 42-volt electrical system.*

\section{Advanced Concept Development}

- Develop and demonstrate a controlled-nucleate-boiling cooling system; project would include fundamental studies of flow boiling mechanisms.

- Evaluate/develop/demonstrate waste-heat-recovery/utilization technologies, including waste heat recovery heat exchangers, thermoelectric converters and storage devices.*

- Evaluate/develop/demonstrate heat-pipe technology.*

\section{Advanced Heat Exchangers and Heat Transfer Fluids}

- Develop new materials (e.g., carbon foams and carbon/carbon composites) for application in cooling system components, including heat exchangers; fabricate and demonstrate prototype heat exchanger.

- Further develop and gain understanding of nanofluid technology for improving heat transfer characteristics of coolants and engine oils; develop and demonstrate product.

- Develop advanced airside heat rejection concepts and heat transfer enhancement techniques that will result in more compact heat exchangers.

- Perform fundamental studies of fouling mechanisms and mitigation, relative to selected enhanced surfaces, including exhaust side of EGR cooler.

\section{Simulation Code Development}

- Develop nonproprietary system code of zero or one dimension to run on a PC; initial task would be a paper study to determine what is already available (e.g., codes, submodels, and validation data) and what the automobile industry is doing that may bear on heavy vehicles.

\footnotetext{
*A "paper study" with industry input is recommended as the initial phase of this project (subtask) to identify the benefits (energy savings, efficiency, performance), barriers (cost, weight, materials, durability), and technical approach.
} 
- Develop/demonstrate/validate computational fluid-dynamic (CFD) models and simulation codes for underhood airflow and temperatures, to be used in integrating the heat exchangers (radiator, charge-air cooler, and condenser) under the hood; couple underhood airflow prediction capability with DOE's current aerodynamics code development.

- Generate standard experimental data base on thermal performance of systems and subcomponents for use in code validation (laboratory component testing and field testing of instrumented on-highway trucks).

- Work with code developers, OEMs, and suppliers to develop a consistent interface specification so that data can be efficiently transferred between codes and code modules.

- Develop framework for a simulation code that ultimately can be used to predict truck fuel economy and emissions for an entire drive cycle (possible sub-models would include power-train, vehicle load prediction, control systems, cooling systems, external aerodynamics, underhood airflow, cooling and refrigeration, lubrication cooling, and cabin airflow).

\section{Sensor and Control Components Development}

- Real-time $\mathrm{NO}_{\mathrm{x}}$ sensor.

- Reliable/robust sensors for critical engine temperatures and coolant and airflow for computer control and feedback.

\section{Concept/Demonstration Truck Sponsorship}

- Sponsor demonstration truck for developing and evaluating new technologies.

- Demonstrate advanced truck thermal management systems at full scale.

\section{Aerodynamic Evaluations}

- Evaluate contribution of underhood airflow to overall aerodynamic drag.

- Evaluate use of shutters for aerodynamic drag control. 
- Determine benefits to be gained, if any, from further reduction of radiator frontal area (or are we facing diminishing returns?). Improved aerodynamics has the potential to substantially increase fuel economy, but streamlining the cab puts a greater demand on the cooling system because of reduced frontal area and a tighter engine compartment.

\section{Related areas}

- Develop non-EGR emission control strategies.

\section{Technological and Cultural Barriers}

One should recognize that the heavy-duty (Class 7-8) truck industry is unique, and differs from the automotive and light truck (e.g., pickup truck and SUV) industries in several important ways: (1) It is a relatively low-volume industry, in terms of numbers of vehicles produced compared to passenger car production, but has national implications relative to fuel usage and emissions production; heavy-duty vehicles (including off-highway, buses, and rail) consume more than $25 \%$ of the fuel used in the transportation sector. (2) Trucks are typically customdesigned, with customers having the option to select the engine and in many cases the cooling system components. (3) Reliability and durability are of the greatest importance (customers expect extended warranties, and a future goal is a "million-mile" truck). (4) On-highway trucks have unique service duties, including steady-state operation, high average speeds, extended idle times, and modern convenience amenities. For these reasons, cooling system demands can be very different from those for light trucks, yet the system designs are the same.

For many of the problems identified in the workshop, technologically feasible solutions already exist but are not being implemented by the industry. In most cases, the reluctance is due to concern that the potential benefits from a new technology cannot justify the added costs. Usually there is insufficient information on both benefits and cost to make a rational decision. Therefore, one potentially important role for DOE would be to help develop such information.

The two general approaches for developing benefits and cost information are modeling and measurement. Modeling of benefits (fuel savings, emission reductions, fewer repairs, etc.) requires complex computer codes that incorporate the behavior of, and interactions between, all major components of the truck, along with air flow around them. Such comprehensive models do not exist (although a number of elements do), and even if they did, they would be too complicated and time-consuming for all but the largest and most sophisticated companies. Therefore, development of simulation codes, both simple and comprehensive, is needed. This is 
an area in which government laboratories have acknowledged expertise which can be brought to bear.

Output from computer models is usually not accepted unless the models have been validated with measured data. Generating such data is very expensive, and frequently the data are unique to each system or manufacturer. Nevertheless, it might be possible for DOE to accumulate a data base that could be used for generic validations. An indisputable data base would be one obtained from detailed measurements from an instrumented truck operated over a specified drive cycle.

Generation of cost information should start with paper studies, but care must be exercised to ensure that all elements and side effects are considered. The output from those paper studies also should be validated from fleet data or dedicated experiments.

A barrier to the application of variable-speed components (drives, fans, pumps, and compressors), which would be much more efficient and would enable new technologies, is the requirement of a 42-volt electrical system in the truck. Rather than change every system on the truck that uses electricity, including lights, radios, and microprocessors, a dual $12-\mathrm{v}$ and $42-\mathrm{v}$ system may be used; the bus/coach industry commonly uses 12-v systems, concurrently with 24$\mathrm{v}$ systems for higher electrical loads. A cost/benefit study is very much needed in this topical area.

Other factors that must be considered are operating costs related to weight, reliability, and durability. If a new device (such as an auxiliary power unit, for example) adds weight to the truck, there will be an equivalent reduction in payload, which reduces the revenue of the trucker. Reduction of reliability and durability cannot be tolerated because of the potential added expenses due to repairs and downtime. Owners must be presented with convincing data on reliability before they will accept new technology.

While cost is a major concern for any new technology, a number of potentially energysaving advanced concepts also face technical barriers. A few examples are as follows:

- A fundamental understanding of flow boiling mechanisms will be required to develop a reliable and effective nucleate-boiling cooling system.

- Effects on erosion and wear of components due to particles in nanofluids must be understood before nanofluid technology will be accepted for improving the heattransfer characteristics of coolants and engine oils. 
- Fouling and pressure-drop issues must be addressed and resolved for the application of advanced heat exchangers that use carbon foam technology.

\section{Multiyear Program Plan}

The goal of the DOE/OHVT Program on Thermal Management for Heavy Vehicles is to contribute to the development and application of advanced thermal management systems for heavy-duty-diesel on-highway trucks, in order to improve engine performance and fuel economy and to reduce emissions. The program includes the development and validation of analytical tools and prediction methods, and the evaluation, development, and demonstration of advanced concepts and designs. A listing of recommended research areas/projects appropriate for government support was developed, based on workshop presentations and breakout session discussion, and presented in Section 3.2 of this report. This listing, coupled with information obtained from literature surveys and selected site visits to truck and engine manufacturers and equipment suppliers [4,5], provide the basis for the development of a DOE/OHVT multiyear program plan as defined by the six task areas described below. An estimate of DOE/OHVT resources required to carry out the tasks over the next 5 years is given in Table 1 of the Executive Summary. In developing the estimate, it was assumed that the research will be costshared with industry. While it is recommended that DOE fund demonstration of advanced concepts and designs, the implementation of such concepts and designs would be left to industry.

\subsection{Task Descriptions}

Industry support of any new research and development project is very important in order to ensure the acceptance and ultimately the implementation of the final product of the research. As a consequence, it is imperative that the task projects be developed and, as appropriate, carried out in cooperation with (and with support from) industry. In particular, the various projects should be carried out as Cooperative Research and Development Agreements (CRADAs), which could involve the national laboratories and universities, with several industrial partners and with industry cost-sharing.

Thermal management is a new program area for DOE/OHVT. As a consequence, in the first years of the program there will be a need for white papers prepared with industry input and/or review and evaluating needs in selected topical areas and identifying research requirements and technical approaches.

Task 1: Program Management/Coordination and Benefits/Cost Analyses. The

objectives of the task are to (a) provide overall program management and coordination/interaction among industrial partners, national laboratories, and universities, and (b) 
identify, evaluate, and quantify energy savings and emissions reduction opportunities enabled by improved truck thermal management systems.

A working group will be formed to review and comment on the research and development tasks being conducted under the DOE/OHVT heavy-duty truck thermal management program. The working group will comprise representatives of engine manufacturers, truck manufacturers, equipment suppliers, coolant and engine oil suppliers, fleet operators, and researchers from national laboratories and universities. Because of the broad and diverse nature of the subject, consideration will be given to forming subgroups in specific topic areas, e.g., heat exchangers and variable-speed components. The working group and subgroups may meet periodically to ensure that the research and development is relevant and responsive to industry needs. The working group will coordinate activities in the thermal management program with those in other OHVT programs in aerodynamic drag, friction and wear, rolling resistance and braking, and propulsion materials.

Truck thermal-management-system requirements are determined in large part by government regulations (e.g., emissions and noise criteria) and customer demands (e.g., higherhorsepower engines, aerodynamic styling, and improved fuel economy). As a consequence, requirements are constantly changing, typically in the direction of increased heat rejection. Follow-up workshops, at which research progress will be reported and industry input solicited, will be arranged and conducted to update thermal-management-system requirements and industry trends. The truck thermal management working group and its subgroups will use the workshops as a forum to report their assessment of the research, new technology needs and future trends. It is anticipated that a retrospective/prospective workshop will be held within 2 to $21 / 2$ years, and a full-plenary workshop, for an updated 5-year plan, will be held in 5 years.

Benefits/cost analyses will be performed to quantify energy savings and emissions reduction potential and to establish and document safety implications of new technologies. It is important to be able to quantify energy savings and emissions reduction associated with improved thermal management systems for at least two reasons. First, to justify higher capital cost, and possibly system complexity, the customer (fleet and individual-owner operators) must be convinced of the energy savings and safety improvements that can accrue. Second, DOE/OHVT must be able to cite and validate these energy savings and emissions reduction to justify its funding requests. The energy savings potential comes from a number of different areas. In particular, energy (fuel) savings and emissions reduction can be attributed to improved engine performance, improved aerodynamics, reduced weight (more cargo carried per truck can reduce the number of trucks on the highway), reduced idling time, and faster engine warm-up. Such contributions must be aggregated to come up with a total benefit. It is important that benefits/cost analyses be performed early in the program and continuously updated as the program evolves. 
Task 2: Advanced-Concept Development. This task addresses the need for new and innovative thermal management concepts, systems, and designs to meet the truck industry's challenge to accommodate increased heat rejection. These concepts can be considered longrange and high-risk - concepts that industry would most likely not explore on its own. The objectives of this task are to identify advanced concepts, survey the state of the art and background relative to each, and, together with the truck industry, assess the benefits, barriers, and feasibility. For those concepts determined to be feasible and promising, further objectives are to develop the technological base, perform proof-of-concept tests, and demonstrate component and/or performance improvements on a concept/demonstration truck. Technology transfer is a high priority in DOE-sponsored programs, and industry must be involved in all stages. One concept recommended for evaluation, development, and demonstration, that is being considered initially with FY00 funding, is nucleate-boiling cooling in a hybrid forcedconvection/nucleate-boiling system.

Other concepts recommended for evaluation include waste heat recovery/utilization technologies and heat-pipe technology. Depending on funding levels, it is anticipated that one or both of these concepts may be selected for development and demonstration, and also that other "new concepts" will be identified and endorsed by the working group for inclusion in the multiyear program plan. Funding allocations for this task in the out-years (see Table 1) are enhanced to allow for this.

Task 3: Advanced Heat Exchangers and Heat Transfer Fluids. In this task, new and innovative heat transfer enhancement methodologies will be evaluated, developed, and demonstrated, together with new materials and designs for heat exchangers, and advanced heat transfer fluids. The heat exchangers (radiator, charge-air cooler, oil coolers, EGR coolers) and heat transfer fluids (coolant, oils, and ambient air) are key components of a truck thermal management system. There is a general interest in reducing the size and weight of the heat exchangers while maintaining reliability and durability. Also, the heat transfer fluids are generally poor from the heat transfer standpoint. As a consequence, heat transfer surface enhancement is of general importance. Recommended developments in enhanced heat transfer and improved heat exchanger performance will initially be achieved in the following areas:

- Advanced airside heat-rejection concepts.

- New materials, such as carbon foams and carbon composites, for heat exchangers.

- Nanofluid technology for improving heat-transfer characteristics of coolants and engine oils.

- Fundamental understanding of fouling mechanisms and mitigation. 
Carbon foam and nanofluid technologies are currently being funded (FY00), and these subtask activities are expected to be continued if proof-of-concept studies so indicate.

Task 4: Simulation-Code Development. This task involves the development, validation, and application of simulation software for the design, development, and optimization of truck thermal-management-systems, and, ultimately, for the prediction of vehicle fuel economy and emissions over an entire drive cycle. Improved management of underhood airflow will maximize heat transfer and minimize contribution to overall aerodynamic drag. Such a code would also help in benefits/cost analyses to quantify the energy savings potentials of new technologies. The automotive industry has been using these simulation techniques in recent years. The trucking industry, working with software developers, is engaging in more and more simulation studies, with much of the work being design-specific and proprietary. A comprehensive computer code to predict fuel economy and emissions for an entire drive cycle, including modules for the power-train, vehicle-load prediction, control systems, cooling systems, external aerodynamics, underhood airflow, cooling and refrigeration, lubricant cooling, and cabin airflow is needed for optimizing future designs. Recommended subtask activities include the following:

- Development of a nonproprietary system code of zero or one dimension to run on a PC; the initial task would be a paper study to determine what is already available (e.g., codes, submodels, and validation data) and what the automobile industry is doing.

- Development/demonstration/validation of CFD models and simulation codes for underhood airflow and temperatures, for use in integrating heat exchangers.

- Integration of computer models for underhood airflow with codes developed for aerodynamic drag prediction [6], and demonstration of the use of such integrated codes to optimize airflow for cooling (heat exchanger efficiency) and aerodynamic drag reduction.

- Collaboration with code developers, OEMs, and suppliers to develop a consistent interface specification so that data can be efficiently transferred between codes and code modules.

- Development of the framework for a simulation code that ultimately can be used to predict truck fuel economy and emissions for an entire drive cycle.

Task 5: Sensors and Control Components Development. This task will identify sensor and control requirements of an advanced computer-controlled thermal-management 
system, evaluate what sensors and controls are available to satisfy these needs, and identify research needed for development of new, more accurate and robust sensors and controls. A computer-controlled thermal management system with demand-responsive control and supply of mass and heat flows to maintain critical engine and engine-related component temperatures within acceptable ranges is a goal of the industry. Such a system requires sensors, actuators, microprocessors, and control algorithms. Sensors are required to measure such parameters as temperature, pressure, and flow rates at critical points in the engine and in the air and coolant circuits. The operating conditions of the engine (speed and torque), fan and pump speeds, and ambient temperature must also be measured. These measured parameters, together with input signals from other components and/or operator commands, would be input to a microprocessorbased control system. The cooling system actuators (valves, and variable-speed pump and fan) would be controlled according to prescribed control objectives. It is important to have requisite sensors and controls available to implement advanced concepts. A reliable and robust real-time sensor for $\mathrm{NO}_{\mathrm{x}}$ is also required to optimally implement various emission control strategies such as EGR. The objective of this task is to identify research needs in sensors and control components, and as required, to develop such components. Activities in this area will be coordinated with ongoing programs within OHVT and other offices of OTT.

Task 6: Concept/Demonstration Truck Sponsorship. This task includes the sponsorship of a fully-instrumented concept truck for (a) the demonstration of new thermal management system concepts and equipment, and (b) the development of a data base of pertinent temperatures, pressures, and flows, as well as fuel economy and emissions reduction information, for various drive cycles. It is imperative that the benefits of any new concepts and technologies be clearly demonstrated for customer (fleet and individual-owner operators) acceptance of such technologies, which may be more expensive initially but have demonstrable payback over time. It is equally important that a data base of temperature, pressure, and flow rate measurements be established for use in the validation and further development/refinement of simulation codes. Validation is crucial if such codes are to be accepted and used by industry to optimize thermal-management systems and underhood airflow for system efficiency and aerodynamic drag reduction.

An example in which a demonstration truck would be important is that of variable-speed components (drives, fans, pumps, and compressors). There is general agreement that such devices would be much more efficient and would enable the application of advanced thermal management concepts such as nucleate-boiling cooling. However, a quantitative measure of efficiency improvements is not currently available and can be determined only from field testing with an instrumented vehicle.

The task of developing and operating a concept truck will involve close coordination and significant cost-sharing with industry. An initial subtask will establish a task force consisting of 
a truck manufacturer(s), engine manufacturer(s), equipment suppliers, and fleet operator(s), which would define the objectives, approach, and operational responsibilities for the concept truck. Question and issues that must be resolved include the following: What are the critical parameters to be measured? What organization should operate the vehicle? What is the protocol for a truck manufacturer or equipment supplier to use the truck to evaluate new designs or concepts? What new sensors and control equipment must be developed and implemented? What data acquisition equipment is required? How will costs be shared between DOE/OHVT and the different companies using the truck?

DOE/OHVT has a longer-range plan to demonstrate a 12-mpg truck that would include all feasible aerodynamic drag-reduction techniques. The concept truck proposed under this task would be the precursor to the 12-mpg demonstration truck, because many of the advanced thermal management system concepts demonstrated and evaluated on the concept truck of this task activity would also be included on the 12-mpg demonstration vehicle.

\subsection{Duration/Budget}

In general, research activities can be conveniently categorized as near-term (1-3 years), mid-term (3-5 years), and long-term (5-10 years). Near-term research is more closely related to product development and is primarily within the province of industry. The DOE is primarily concerned with longer-range, higher-risk research, which falls in the mid- and long-term ranges. An estimate of the annual DOE/OHVT resources required to carry out the six tasks over the next 5 years (FY01 - FY05) is summarized in Table 1; Table 1 also shows current (FY00) funding. The estimated DOE/OHVT budget requirements assumes industry cost-sharing an equal or greater amount, thereby leveraging the contributions of both parties.

\section{Acknowledgments}

The many and varied contributions of the workshop participants, who shared their knowledge of the state of the art and trends in truck thermal management, and their vision of what research and development is required in the future, are gratefully acknowledged. The speakers, as well as the workshop facilitators and recorders, deserve special acknowledgment for the extra effort that they put forward. The presentation summaries given in Section 2 were, for the most part, taken verbatim from the speakers' presentation materials. Dr. Raymond Fessler, BIZTEK Consulting, Inc., assisted in soliciting workshop participants and speakers. 


\section{References}

1. OHVT Technology Roadmap, Office of Heavy Vehicle Technologies, Office of Transportation Technology, DOE/OSTI-11690, Oct. 1997.

(URL: http://www.osti.gov/roadmap.pdf)

2. Multiyear Program Plan for 1998-2002, Office of Heavy Vehicle Technologies, Office of Transportation Technology, DOE/ORO-2071, Aug. 1998.

(URL: http://www.osti.gov/multiyr.pdf)

3. DOJ/EPA Consent Decree, EPA Headquarters Press Release, October 22, 1998.

(URL: http://es.epa.gov/oeca/ore/aed/diesel/)

4. Wambsganss, M. W., "Thermal Management in Heavy Vehicles: A Review Identifying Issues and Research Requirements," Vehicle Thermal Management Systems-4, Professional Engineering Publishing, Ltd., London, Paper No. C543/086/99, pp. 651-664, 1999.

5. Wambsganss, M. W., "Thermal Management Concepts for Higher-Efficiency Heavy Vehicles," presented at SAE Government/Industry Meeting, Washington, DC, SAE Paper No. 1999-01-2240, 1999.

6. McCallen, R., "Potential for Aerodynamic Drag Reductions for Higher Efficiency HeavyDuty (Class 7-8) Trucks," presented at SAE Government/Industry Meeting, Washington, DC, SAE Paper No. 1999-01-2238, 1999. 


\section{Appendix A: Workshop Agenda}

\begin{tabular}{|l|l|}
\hline & U.S. Department of Energy \\
& Workshop on Thermal Management for Heavy Vehicles \\
\hline Monday, October 18, 1999 & Registration, Sign-up for Breakout Sessions, and Reception - \\
Argonne Guest House, Bldg. 460 \\
\hline 6:00 pm \\
U.S. DOE Program on Heavy Vehicle Technologies \\
Jim Eberhardt, Director, Office of Heavy Vehicle Technologies, \\
U.S. Department of Energy
\end{tabular}

Tuesday, October 19, 1999

7:30 am Continental Breakfast - Gallery, Bldg. 402

8:00 am Registration - Auditorium, Bldg. 402

Welcome and Introduction

8:30-8:40 am Welcome

8:40-9:10 am U.S. DOE Program on Vehicle System Technologies

Sid Diamond, Team Leader, Office of Heavy Vehicle Technologies,

U.S. Department of Energy

9:10-9:30 am Introduction: Background/Objectives

Marty Wambsganss, Argonne National Laboratory

\section{Keynote Presentations}

9:30-10:00 am Heavy-Duty Diesel Engine Cooling

Mark Moeckel, Caterpillar Incorporated

10:00-10:15 am Break

10:15-10:45 am Thermal Management in the Design of Large Trucks

Bob Weber, Navistar International Transportation Corp.

10:45-11:00 am Energy and Emissions Impacts of Heavy Vehicles

Frank Stodolsky, Argonne National Laboratory

Panel Discussion on State of the Art/lssues/Industry Needs

11:00-11:25 am Heat Transfer Fluids (Coolants, Oils)

Fran Lockwood, The Valvoline Company

11:25-11:50 am Heat Exchangers (Radiators, CACs, Oil Coolers, EGR Coolers)

Steve Memory, Modine Manufacturing Company

12:00-1:00 pm Lunch-Gallery, Bldg. 402

1:00-1:25 pm Cooling Fan and Fan Clutch Technologies

Jim Bailey/Gene Wantuck, Borg-Warner Automotive Cooling Systems

1:25-1:50 pm Coolant Pumps

Mike Lasecki, Engineered Machined Products, Inc.

1:50-2:15 pm Emissions Regulations and Engine Durability

Steve Zoz, Ricardo, Inc. 
Tuesday, October 19, 1999 (Cont.)

\begin{tabular}{|c|c|}
\hline $2: 15-2: 40 \mathrm{pm}$ & $\begin{array}{l}\text { Cab Climate Control } \\
\text { Terry Zeigler, Bergstrom Manufacturing Corporation }\end{array}$ \\
\hline $2: 40-3: 05 \mathrm{pm}$ & $\begin{array}{l}\text { Cab/Sleeper Climate Control @ '0’ mpg } \\
\text { Roman Suter, Webasto Thermosystems Inc. }\end{array}$ \\
\hline $3: 05-3: 25 \mathrm{pm}$ & Break \\
\hline $3: 25-3: 50 \mathrm{pm}$ & $\begin{array}{l}\text { Transport Refrigeration } \\
\text { Lim Kwon, Thermo King Corporation }\end{array}$ \\
\hline $3: 50-4: 15 \mathrm{pm}$ & $\begin{array}{l}\text { Modeling and Simulation } \\
\text { Steve MacDonald, adapco }\end{array}$ \\
\hline $4: 15-4: 40 \mathrm{pm}$ & $\begin{array}{l}\text { Aerodynamics and Underhood Airflow } \\
\text { Rose McCallen, Lawrence Livermore National Laboratory }\end{array}$ \\
\hline $4: 40-5: 05 \mathrm{pm}$ & Brake Cooling (TBD) \\
\hline $6: 00 \mathrm{pm}$ & $\begin{array}{l}\text { Reception (Cash Bar) and Banquet - Argonne Guest House, Bldg. } 460 \\
\text { Banquet Address: } \mathbf{2 1}^{\text {st }} \text { Century Truck Initiative } \\
\text { Paul Skanly, U.S. Army TACOM }\end{array}$ \\
\hline
\end{tabular}

Wednesday, October 20, 1999

7:15 am Continental Breakfast - Gallery, Bldg. 402

Panel Discussion on Advanced Thermal Management Concepts/Design

8:00-8:25 am Computer-Controlled Thermal Management Systems John Johnson, Michigan Technological University

8:25-8:50 am Compact Cooling System (Radial Fan) Jonathan Wattelet/Tom Shields, Modine Manufacturing Company

8:50-9:15 am Radiator Design/Positioning Vic Suski, American Trucking Associations

9:15-9:40 am Hybrid Forced-Convection/Nucleate-Boiling Cooling/Precision David France, University of Illinois at Chicago

9:40-10:05 am Loop Heat Pipe Technology Paul Rogers, U.S. Army TARDEC

10:05-10:20 am Break

10:20-10:50 am Lightweight, High-Conductivity Materials Roland Watts, AFRL-Wright Patterson Air Force Base James Klett, Oak Ridge National Laboratory

10:50-11:15 am Nanofluids for Thermal Management in Heavy Vehicles Steve Choi, Argonne National Laboratory George Zhang, The Valvoline Company

11:15-11:40 am Waste Heat Recovery/Utilization Alan Montemayor, Southwest Research Institute

$11: 45$ am12:45 pm Lunch - Gallery, Bldg. 402 
Wednesday, October 20, 1999 (Cont.)

\section{Simultaneous Technical Breakout Sessions to Develop Research Agendas}

12:45-3:30 pm Discussion Group Meetings

Session A: Engine cooling methodologies/system architectures, computer-controlled systems (Facilitator: Mark Moeckel, Caterpillar Incorporated); Auditorium, Bldg. 402

Session B: Heat exchangers, heat transfer fluids, heat transfer enhancements, cab climate control, refrigeration

(Facilitator: Joe McCorkel, Freightliner Corporation); Room E1100, Bldg. 402

Session C: Fans, pumps, actuators, sensors, waste heat recovery/utilization, heat storage, brake cooling, auxiliary power units (Facilitator: Mike Russell, Kenworth Truck Company); Room E1200, Bldg. 402

Session D: Modeling, simulation, underhood airflow, aerodynamics

(Facilitator: Steve Zoz, Ricardo, Inc.); Room A1100, Bldg. 402

3:30-3:50 pm Break

3:50-4:20 pm Breakout Sessions Reports

4:20-4:30 pm Wrap-up

Marty Wambsganss, Argonne National Laboratory

4:30 pm Adjourn 


\section{Appendix B: Workshop Participants}

David Allen

Engineered Machined Products, Inc. 2701 N. $30^{\text {th }}$ Street

Escanaba, MI 49829

Tel: 906-789-7497 ext. 304

Fax: 906-789-7825

dallen@,up.net

Mark Bader

Engineered Machined Products, Inc. 2701 N. $30^{\text {th }}$ Street

Escanaba, MI 49829

Tel: 906-789-7497 ext. 316

Fax: 906-789-7825

James W. Bailey

Borg-Warner Automotive

Cooling Systems Division

6040 West $62^{\text {nd }}$ Street

Indianapolis, IN 46278

Tel: $317-328-3179$

Fax: 317-328-3292

ibailey@turbos.bwauto.com

George Eugene (Gene) Barron

Freightliner Corporation

4747 N. Channel Ave.

Portland, OR 97217

Tel: 503-735-8440

Fax: 503-735-6800

GeneBarron@Freightliner.com

Jeffrey B. Berge

Thermo King Corporation

314 West $90^{\text {th }}$ Street

Minneapolis, MN 55420

Tel: 612-887-2231

Fax: 612-887-2606

berge@,thermoking.com

Lawrence J. Biess

CSX Transportation

500 Water Street

Jacksonville, FL 32202

Tel: 904-359-7424

Fax: 904-359-3015

Larry Biess Notes@,CSX.com
Dan Blurton

Western Star Trucks, Inc.

2076 Enterprise Way

Kelowna, BC V1Y 6H8

Canada

Tel: $250-868-6250$ ext. 5508

Fax: 250-470-1907

dblurton@wstar.com

Rodge Brooks

Sanden International

601 S. Sanden Blvd.

Wylie, TX 75098

Tel: 972-442-8574

Fax: 972-442-8700

rbrooks@sanden.com

Charles N. Brown, Jr.

American Cooling Systems, LLC

$551033^{\text {rd }}$ Street SE

Grand Rapids, MI 49512

Tel: 616-954-0280 ext. 113

Fax: 616-954-0283

cnbrown@americancooling.com

Stephen U. Choi

Argonne National Laboratory

9700 S. Cass Avenue - Bldg. 335

Argonne, IL 60439

Tel: 630-252-6439

Fax: 630-252-5568

choi@anl.gov

David D. Colavincenzo

Detroit Diesel Corporation

13400 Outer Drive West

Detroit, MI 48239-4001

Tel: 313-592-0266

Fax: 313-592-5906

david.colavincenzo@detroitdiesel.com

Sam J. Collier

Modine Climate Systems Inc.

551 Tapp Road

P.O. Box 367

Harrodsburg, KY 40330-0367

Tel: 606-734-1626

Fax: 606-734-8261

s.j.collier@modine.com 
William R. Corwin

Oak Ridge National Laboratory

Metals and Ceramics Division

P.O. Box 2008, 4500 S, MS-6161

Oak Ridge, TN 37831-6161

Tel: 423-574-4648

Fax: 423-574-4066

corwinwr@ornl.gov

Rich Couch

Lawrence Livermore National Laboratory

B Division

7000 East Ave., L-099

Livermore, CA 94550

Tel: 925-422-1655

couch1@LLNL.GOV

Rolando (Roy) M. Cuenca

Argonne National Laboratory

9700 S. Cass Avenue ES/362

Argonne, IL 60439

Tel: 630-252-9175

Fax: 630-252-3443

rcuenca@anl.gov

Philip B. Cutler

Engineered Cooling Systems, Inc.

201 W. Carmel Drive

Carmel, IN 46032

Tel: 317-846-3438 ext. 236

Fax: 317-846-3460

pbcutler@ecsfans.com

Emile (Skip) E. Damotte

Caterpillar Inc.

Analysis Tool Development

100 NE Adams St.

Peoria, IL 61629-9760

Tel: 309-494-4691

Fax: 309-494-4715

Sidney Diamond

Department of Energy

Office of Heavy Vehicle Technologies

EE-33

1000 Independence Ave., S.W.

Washington, D.C. 20585-0121

Tel: 202-586-8032

Fax: 202-586-4166

sid.diamond@ee.doe.gov
James J. Eberhardt

Department of Energy

Office of Heavy Vehicle Technologies

EE-33

1000 Independence Ave., S.W.

Washington, D.C. 20585-0121

Tel: 202-586-1694

Fax: 202-586-4166

James.eberhardt@ee.doe.gov

Raymond R. Fessler

BIZTEK Consulting, Inc.

820 Roslyn Place

Evanston, IL 60201-1724

Tel: 847-733-7410

Fax: 847-733-9541

BIZTEKRRF@aol.com

David M. France

University of Illinois at Chicago

842 W. Taylor St. (m/c 251)

Chicago, IL 60607-7022

Tel: 312-996-0520

Fax: 312-996-8664

DFrance@,uic.edu

Venkat Ganapathy

Ricardo, Inc.

7850 Grant Street

Burr Ridge, IL 60521

Tel: 630-789-0003 ext. 204

Fax: 630-789-0127

vganapathy@,ricardo-us.com

Norman C. Golm

Air International

1124 Centre Street

Auburn Hills, MI 48326

Tel: $248-370-8623$

Fax: 248-370-8618

Ngolm@,compuserve.com

Joseph C. Hamilton

American Cooling Systems

$551033^{\text {rd }}$ Street SE

Grand Rapids, MI 49512

Tel: 616-954-0280

Fax: 616-954-0283

ihamilton@americancooling.com 
Tara L. Hemami

Cummins Engine Company

Mail Code 50180

1900 McKinley Ave.

Columbus, IN 47201

Tel: 812-377-5755

Fax: 812-377-7808

tara.1.hemami@,ctc.cummins.com

Beth M. Holloway

Cummins Engine Company

Mail Code 50180

1900 McKinley Ave.

Columbus, IN 47201

Tel: 812-377-7874

Fax: 812-377-7808

Beth.M.Holloway@,Cummins.com

Jonathan P. Jackson

Detroit Diesel Corporation

13400 Outer Drive West

Detroit, MI 48239

Tel: 313-592-7692

Fax: 313-592-5906

jjacks01@,DetroitDiesel.com

Sunil K. Jain

Navistar International Transportation Corp.

2911 Meyer Road

P.O. Box 1109

Fort Wayne, IN 46801

Tel: 219-428-3783

Fax: 219-461-1394

Sunil.Jain@,navistar.com

Chadwick N. Johnson

Oshkosh Truck Corporation

2307 Oregon St. P.O. Box 2566

Oshkosh, WI 54903-2566

Tel: 920-235-9151

Fax: 920-235-9252

cjohnson@oshtruck.com

D. Ray Johnson

Oak Ridge National Laboratory

Metals and Ceramics Division

P.O. Box 2008

Oak Ridge, TN 37831-6066

Tel: 423-576-6832

Fax: 423-574-6098

iohnsondr@,ornl.gov
John H. Johnson

Michigan Technological University

815 R.L. Smith ME-EM Bldg

1400 Townsend Drive

Houghton, MI 49931-1295

Tel: 906-487-2576

Fax: 906-487-2822

ijohnson@mtu.edu

Larry R. Johnson

Argonne National Laboratory

9700 S. Cass Avenue ES/362

Argonne, IL 60439

Tel: 630-252-5631

Fax: 630-252-4211

johnson@anl.gov

Joseph S. Juger

G\&O Manufacturing Company

100 Gando Drive

New Haven, CT 06513

Tel: 203-562-5121

Fax: 203-789-8760

jiuger@,transpro.com

Keith R. Karasek

AlliedSignal, Inc.

50 East Algonquin Road

Des Plaines, IL 60016

Tel: 847-391-3341

Fax: 847-391-3653

Keith.Karasek@,AlliedSignal.com

Mohammed A. Khaleel

Pacific Northwest National Lab

P.O. Box 999, Battelle Blvd, MS K2-18

Richland, WA 99352

Tel: 509-375-2438

Fax: 509-375-2426

MOE.KHALEEL@PNL.GOV

Carl Kiser

AlliedSignal Turbocharging Systems

3201 West Lomita Blvd

Torrance, CA 90505

Tel: 310-517-1929

Fax: 310-257-2445

carl.kiser@alliedsignal.com

James W. Klett

Oak Ridge National Laboratory

P.O. Box 2008

Oak Ridge, TN 37831-6087

Tel: 423-574-5220

Fax: 423-576-8424

klettjw@ornl.gov 
Mike H. Kohler

Mack Trucks

2100 Mack Blvd.

Allentown, PA 18105

Tel: 610-709-2598

Fax: 610-709-2121

mike.kohler@macktrucks.com

John Kolb

G\&O Manufacturing Company

100 Gando Drive

New Haven, CT 06513

Tel: 203-562-5121

Fax: 203-789-8760

kolb@,transpro.com

Sung Lim Kwon

Thermo King Corporation

314 West $90^{\text {th }}$ Street

Minneapolis, MN 55420

Tel: 612-887-2256

Fax: 612-887-2606

Sung-Lim-Kwon@thermo.com

James R. (Roger) Lackore

Pierce Manufacturing

2600 American Drive

Appleton, WI 54912

Tel: 920-832-3249

Fax: 920-832-3092

Brian K. Larche

Engineered Machined Products, Inc.

3111 N. $28^{\text {th }}$ Street

Escanaba, MI 49829

Tel: 906-786-8404 ext. 126

Fax: 906-789-9773

BLARCHE@,EMP-CORP.COM

Mike Lasecki

Engineered Machined Products, Inc.

2701 N. 30 ${ }^{\text {th }}$ Street

Escanaba, MI 49829

Tel: 906-789-7497 ext. 319

Fax: 906-789-7825

Robert M. Lattin

Thermo King Corporation

314 West $90^{\text {th }}$ Street

Minneapolis, MN 55420

Tel: 612-887-2498

Fax: 612-887-2606

rlattin@thermoking.com
Frances E. Lockwood

The Valvoline Company

P.O. Box 14000

Lexington, KY 40512

Tel: 606-357-7867

Fax: 606-357-2255

felockwood@ashland.com

Peter S. (Steve) MacDonald

adapco (Analysis and

Design Application Co.)

60 Broadhollow Road

Melville, NY 11747

Tel: 516-549-2300

Fax: 516-549-2654

psm@adapco.com

Tony Markel

National Renewable Energy Lab

Center for Transportation Technologies and Systems

1617 Cole Blvd

Golden, CO 80401

Tel: 303-275-4478

Fax: 303-275-4415

Tony Markel@,NREL.GOV

David Martin

AlliedSignal Turbocharging Systems

3201 West Lomita Blvd

Torrance, CA 90505

Tel: 310-517-1465

Fax: 310-257-2445

david.martin@alliedsignal.com

Rose C. McCallen

Lawrence Livermore National Laboratory

P.O. Box 808

7000 East Ave., MailStop L-98

Livermore, CA 94550

Tel: 925-423-0958

Fax: 925-422-3389

mccallen1@1lnl.gov

Joseph H. McCorkel

Freightliner Corporation

P.O. Box 3849

Portland, OR 97208-3849

Tel: 503-735-6998

Fax: 503-735-8819

JosephMcCorkel@,Freightliner.com 
April D. McMillan

Oak Ridge National Laboratory

P.O. Box 2008, 1 Bethel Valley Road

Oak Ridge, TN 37831-6087

Tel: 423-241-4554

Fax: 423-574-8271

mcmillanad@,ornl.gov

Stephen B. Memory

Modine Manufacturing Company

1500 DeKoven Avenue

Racine, WI 53403

Tel: 414-636-1337

Fax: 414-636-1424

s.b.memory@,modine.com

Edgar H. Middlehoven

PACCAR Technical Center

12479 Farm to Market Road

Mount Vernon, WA 98273

Tel: 360-757-5252

Fax: 360-757-5378

emiddlehoven@,Paccar.com

Ray M. Miraflor AlliedSignal Turbocharging Systems 3201 West Lomita Blvd MS V-12

Torrance, CA 90505

Tel: 310-257-2472

Fax: 310-257-2421

Raymond.Miraflor@alliedsignal.com

Mark. D. Moeckel

Caterpillar Incorporated

Technical Center, Bldg. F

P.O. Box 1875

Peoria, IL 61656-1875

Tel: 309-578-4383

Fax: 309-578-9900

moeckel-mark-d@cat.com

Alan F. Montemayor

Southwest Research Institute

6220 Culebra Rd.

San Antonio, TX 78228-0510

Tel: 210-522-6940

Fax: 210-522-5720

amontemayor@swri.org
Donald R. Musick

Navistar International Transportation Corp.

2911 Meyer Road

P.O. Box 1109

Fort Wayne, IN 46801-1109

Tel: 219-461-1051

Fax: 219-461-1698

Donald.Musick@navistar.com

Eberhard G. Pantow

Behr GmbH \& Co.

Siemensstrasse 164

Stuttgar 70469 Germany

Tel: +49-711-896-3594

Fax: +49-711-896-4696

eberhard.pantow@behrgroup.com

Arvid E. Pasto

Oak Ridge National Laboratory

HTML, Bldg. 4515, MS 6062

Oak Ridge, TN 37831-6062

Tel: 423-574-5123

Fax: 423-574-4913

pastoae@ornl.gov

Reinhard Radermacher

University of Maryland

ME Department

College Park, MD 20742-3035

Tel: 301-405-5286

Fax: 301-405-2025

rader@eng.umd.edu

Chris L. Riley

Cummins Engine Company, Inc.

1900 McKinley Ave. M/C 50231

Columbus, IN 47201

Tel: 812-377-7646

Fax: 812-377-7592

hg947@ctc.cummins.com

Paul D. Rogers

U.S. Army TARDEC

AMSTA-TR-R, Mail Stop 263

Warren, MI 48397-5000

Tel: 810-574-5664

Fax: 810-574-6145

rogersp@,TACOM.army.mil 
Jules Routbort

Argonne National Laboratory

9700 S. Cass Avenue - Bldg. 212

Argonne, IL 60439

Tel: 630-252-5065

Fax: 630-252-4798

routbort@anl.gov

Mike Russell

Kenworth Truck Company

10630 NE $38^{\text {th }}$ Place

Kirkland, WA 98033

Tel: 425-828-5033

Fax: 425-828-5097/5267

mrussell@paccar.com

Raj Sekar

Argonne National Laboratory

9700 S. Cass Avenue ES/362

Argonne, IL 60439

Tel: 630-252-5101

Fax: 630-252-3443

rsekar@anl.gov

Ross D. Sheckler

Dynacs Engineering Co.

PO Box 247

Cato, NY 13113

Tel: 315-626-6800

Fax: 315-626-6787

dynacsny@dynacs.com

Thomas M. Shields

Modine Manufacturing Company

1500 DeKoven Avenue

Racine, WI 53403

Tel: 414-636-1430

Fax: 414-636-1424

t.m.shields@,modine.com

Paul Skalny

U.S. Army TACOM

National Automotive Center (AMSTA-TR-N)

MS 272

Warren, MI 48397-5000

Tel: $810-574-5436 / 8666$

skalnyp@cc.tacom.army.mil

Philip S. Sklad

Oak Ridge National Laboratory

Metals and Ceramics Division

P.O. Box 2008, 1 Bethel Valley Road

Oak Ridge, TN 37831-6065

Tel: 423-574-5069

Fax: 423-576-4963

pxi@ornl.gov
Mark Slivinski

Industrial Advisory Board

University of Illinois at Chicago

303 W. Madison, Suite 1100

Chicago, IL 60606

Tel: 312-658-6424

Fax: 312-658-1093

Frank Stodolsky

Argonne National Laboratory

Energy Systems Division

9700 S. Cass Avenue

Argonne, IL 60439

Tel: 202-488-2431

Fax: 202-488-2444

fstodolsky@anl.gov

Steve Strepek

Ricardo, Inc.

7850 Grant Street

Burr Ridge, IL 60521

Tel: 630-789-0003

Fax: 630-789-0127

sstrepek@ricardo-us.com

Victor Suski

American Trucking Associations 2200 Mill Road

Alexandria, VA 22314-4677

Tel: 703-838-1846

Fax: 703-683-1934

Vsuski@trucking.org

Roman L. Suter

Webasto Thermosystems Inc. 3333 John Conley Drive

Lapeer, MI 48446

Tel: 810-245-2400 ext. 427

Fax: 810-664-7720

webasto@,bignet.net

David J. Twichell

Valeo Engine Cooling

2258 Allen Street

Jamestown, NY 14701

Tel: 716-665-7116

Fax: 716-665-7105

Richard A. Valentin

Argonne National Laboratory

9700 S. Cass Avenue - Bldg. 308

Argonne, IL 60439

Tel: 630-252-4483

Fax: 630-252-3250

richv@anl.gov 
James N. Varner

Pierce Manufacturing

2600 American Drive

Appleton, WI 54912

Tel: 920-832-3458

Fax: 920-832-3092

Martin W. Wambsganss

Argonne National Laboratory

9700 S. Cass Avenue - Bldg. 335

Argonne, IL 60439

Tel: 630-252-6144

Fax: 630-252-5568

wambsganss@anl.gov

Eugene R. Wantuck

Borg-Warner Automotive

Cooling Systems Division

6040 West $62^{\text {nd }}$ Street

Indianapolis, IN 46278

Tel: $317-328-3988$

Fax: 317-328-3292

gwantuck@turbos.bwauto.com

Richard Wares

Department of Energy

Office of Heavy Vehicle Technologies

EE-33

1000 Independence Ave., S.W.

Washington, D.C. 20585

Tel: 202-586-8031

Richard.wares@ee.doe.gov

Jonathan P. Wattelet

Modine Manufacturing Company

1500 DeKoven Avenue

Racine, WI 53403

Tel: 414-636-1496

Fax: 414-636-1424

i.p.wattelet@,modine.com

Roland J. Watts

Air Force Research Lab/VACD

2130 Eighth Street STE 1

Wright Patterson Air Force Base

Ohio 45433-7542

Tel: 937-255-3021

Roland.Watts@,va.wpafb.af.mil
Evan S. Waymire

Freightliner Corporation

P.O. Box 3849

Portland, OR 97208-3849

Tel: 503-735-7896

Fax: 503-735-7464

EvanWaymire@,Freightliner.com

Robert A. Weber

Navistar International Transportation Corp.

2911 Meyer Road

Fort Wayne, IN 46801

Tel: 219-461-1080

Fax: 219-461-7532

Bob.Weber@Navistar.Com

Terry Zeigler

Bergstrom Mfg Corporation

2390 Blackhawk Rd.

Rockford, IL 61125

Tel: 815-874-7821 ext. 2100

Fax: 815-874-2144

TZeigler@bergstrominc.com

Zhiqiang (George) Zhang

The Valvoline Company

251 Dabney Drive

Lexington, KY 40509

Tel: 606-357-3510

Fax: 606-357-3530

zzhang@ashland.com

Steven C. Zoz

Ricardo, Inc.

9059 Samuel Barton Dr.

Belleville, MI 48111

Tel: 734-397-6676 ext. 2377

Fax: 734-397-6677

Szoz@ricardo-us.com 


\section{Appendix C: Breakout Session Summaries}

\section{BREAKOUT SESSION A}

\section{Engine Cooling Methodologies/System Architectures, Computer-Controlled Systems}

Facilitator: Mark Moeckel, Caterpillar Inc.

Recorder: David France, U. of Illinois at Chicago

\section{Participants:}

Don Musick, Navistar

Beth Holloway, Cummins

Tara Hemami, Cummins

Bob Weber, Navistar

April McMillan, ORNL

Robert Lattin, Thermo King

Gene Wantuck, BWA Cooling Systems

Skip Damotte, Caterpillar

Brian Larche, EMP

Mark Bader, EMP

Carl Kiser, AlliedSignal

Eberhard Pantow, Behr

Jon Jackson, Detroit Diesel

Tom Shields, Modine

Steve Strepek, Ricardo

Roy Cuenca, ANL

John Kolb, G\&O Manufacturing

Dan Blurton, Western Star

\section{Summary:}

The group discussed, somewhat at random, many issues related to engine cooling. Then after some discussion, priorities were set for long- and short-term items. Issues discussed were

1. Selective cooling where each area would receive only the cooling it required.

2. Larger-capacity control module for integrated system control. 
3. Nucleate boiling for

a. precision cooling.

b. engine heat removal with lower coolant flow rate.

4. Increase maximum allowable temperature out of the engine, and increased $\Delta \mathrm{T}$ across it.

5. Consider the air-side heat transfer situation which is controlling.

6. Increase radiator air-side surface.

7. Use variable-speed coolant pump to bring the engine to temperature and to maintain that temperature. Laminar flow can be avoided when the air side does not dominate. (Bosch found 5\% fuel economy improvement with such a system.)

8. Improve control of coolant using variable-speed pump, variable-drive fan, and control as a system.

9. Consider alternate materials for radiator air-side heat transfer (like porous materials).

10. Use large-diameter fans, but control the increased noise.

11. Raise the allowable coolant temperature to about $260^{\circ} \mathrm{F}$.

12. Use improved fluid sensors to control coolant flow.

13. Size coolant system near maximum service, and turn off EGR at the very peak loads.

The prioritization that resulted was

\section{Short Term}

1. Use higher coolant temperature in the range of $240^{\circ} \mathrm{F}$ to $250^{\circ} \mathrm{F}$ with more uniform cooling and increased reliability of temperature sensors.

2. Use variable-speed fan drives and coolant pump.

3 . Increase air-side heat rejection $30 \%$ and underhood air flow reduction of 10 $15 \%$.

4. ECU communication is important, e.g., transmission integration.

5. Develop a non-EGR strategy.

\section{Long Term}

1. Demonstrate improved vehicle cooling systems at full scale with an ECU standard.

2. Evaluate non-EGR emissions-reduction options.

3. Explore advanced air-side heat-rejection concepts.

4. Change emission standard to $\mathrm{g} /$ mile basis; may require a real-time $\mathrm{No}_{\mathrm{x}}$ sensor.

5. Develop a fuel specification for reduced emissions. 


\section{BREAKOUT SESSION B}

\section{Heat Exchangers, Heat Transfer Fluids, Heat Transfer Enhancements, Climate Control, Refrigeration}

Facilitator: Joe McCorkel, Freightliner Corporation

Recorder: Jules Routbort, ANL

\section{Participants:}

Lim Kwon, Thermo King

Steve Memory, Modine

Richard Wares, DOE

Paul Rogers, U.S. Army TARDEC

Phil Sklad, ORNL

Raj Sekar, ANL

James Klett, ORNL

Sam Collier, Modine

Steve Choi, ANL

David Colavincenzo, Detroit Diesel

Joe Juger, G\&O Manufacturing

George Zhang, Valvoline

Fran Lockwood, Valvoline

Mike Kohler, Mack Trucks

Roger Lackore, Pierce Manufacturing

Chad Johnson, Oshkosh Truck

Ed Middelhoven, PACCAR

Bill Corwin, ORNL

Roland Watts, WPAFB

\section{Summary:}

Much of the discussion focused on the radiator and the air-side heat removal. It was felt that with the additional heat load (20 to 50\%) of an EGR heat exchanger, it would be a challenge simply to keep the radiator size constant. The emphasis was on compact systems; radial fans, which are in the advanced prototype stage; and development of more advanced fans. Throughout the discussions, durability was emphasized. It was also mentioned several times that most of any new radiator technology could be applied to reefer technology. Some of the most important areas worthy of DOE support are enumerated below. 
Packaging: Need for integration of heat exchangers, CFD modeling of underhood flow and temperatures, simulation studies.

Nucleate boiling: Need to control nucleate boiling.

Materials: The new carbon foams could have potential for air-side heat removal and should be supported. These materials could have applicability in refrigeration units.

Nanoparticles: The heat capacity of fluids containing nanoparticles generated interest, not so much for the radiator, but possibly for engine cooling. There is a concern that nanoparticles of copper in a lubricating oil might cause havoc with wear, but no one knows, and data are needed.

Other topics that were deemed worthy of DOE support, but that have longer-range goals were adaptive air conditioning, heat pipes, and utilization of exhaust heat. Heat pipes are presently very expensive.

Another need is that there seems to be no standard "fouling" test for heat exchangers. This might not be an appropriate task for DOE, but rather for something like an ASME standard committee. DOE should be more interested in the mechanisms involved in fouling.

R\&D on EGR heat exchangers was felt to be unnecessary, while R\&D on radial fans was deemed short-termed.

\section{BREAKOUT SESSION C}

Fans, Pumps, Actuators, Sensors, Waste Heat Recovery/Utilization, Heat Storage, Brake Cooling, Auxiliary Power Units

Facilitator: Mike Russell, Kenworth Truck Co.

Recorder: $\quad$ Ray Fessler, BIZTEK Consulting, Inc.

\section{Participants:}

David Allen, Engineered Machined Products, Inc.

Jim Bailey, Borg-Warner Cooling Systems

Jeff Berge, Thermo King Corp.

Rodge Brooks, Sanden International

Phillip Cutler, Engineered Cooling Systems

Keith Karasek, AlliedSignal, Inc.

Michael Lasecki, Engineered Machined Products

David Twichell, Valeo Engine Cooling 


\section{Summary:}

After self-introductions, each of the 20 suggested discussion topics was discussed very briefly. Virtually every one had some potential benefits in terms of fuel efficiency (increased mpg), performance, weight reduction, and/or cost reduction. However, the strong consensus was that variable-speed drives, pumps and compressors were the most important topics. These variable-speed components would allow designers to optimize system-level efficiency and performance, plus reduce cost, reduce weight, and increase durability. Variable-speed pumps could be applied to a variety of systems including EGR, HVAC, and engine cooling.

The primary barrier to the use of variable speed components is availability of electric power; a 42-volt electric system would be needed. The 42-v level has been accepted by the industry in principle (even though not in practice) because it is comfortably below the level where an electric shock can be felt (about $50 \mathrm{v}$ ) and well below the lethal level of about $70 \mathrm{v}$.

While everyone in the room agreed that a $42-\mathrm{v}$ system would be far superior to the current $12-v$ system, it was not immediately obvious why the industry had not converted to the higher-voltage system. Clearly, changing the voltage is not a trivial matter. It would require changing every system on the truck that used electricity. This would include lights, radios, and microprocessors. In order to deal with the existing fleet and its $12-\mathrm{v}$ system in addition to future trucks with a 42-v system, manufacturers would have to produce components for both voltage levels, and suppliers would have to stock twice as many parts for many years. It is not obvious to many stakeholders that the economic benefits of a 42-v system would offset the costs of implementing it.

Therefore, it was recommended that DOE fund a two-phase project to clarify the issue. The first phase would be a paper study where all of the known or estimated benefits and costs are tabulated and compared. If the results of the paper study are positive, then a concept vehicle should be constructed with a 42-v electrical system and the variablespeed components that it would enable. The concept vehicle could then be used to convince key stakeholders of the benefits.

The second most significant issue identified by the group was that of turning off the engine when the truck is at a rest stop. It is a "no-brainer" that substantial fuel savings would be achieved in this way. However, some power usually is required - even when the truck is at rest - to maintain the cab climate and "hotel" loads and to restart the engine. This requires either "shore power" at rest stops, which is not generally available at this time and would be expensive to install, or an auxiliary power unit (APU) on every 
truck. The latter option would add weight and cost and appears to be less efficient than the shore-power alternative. It was felt that the time to achieve one or the other alternative could be shortened significantly if DOE would fund a paper study to quantify the benefits versus costs, publicize the results of the study, and support a demonstration program to convince skeptics.

A number of other topics were recognized as having energy-saving potential, but they were considered of lower priority, and time did not permit a detailed discussion of each. Following are some of the comments that were made:

Shutters: In the past, shutters in front of the radiator had been widely used, but less than $1 \%$ of new trucks have them. While they are no longer needed for temperature control, the group speculated that they might be useful for aerodynamic reasons. However, they need clarification of comments made by Rose McCallen regarding the energy loss associated with air flow through the engine compartment. It was suggested that DOE clarify, confirm, and, if necessary, validate those comments.

Nanofluids: More efficient heat-transfer fluids hold the potential for weight reduction because less fluid would be required. This also offers the potential for cost reduction unless the cost of the new fluid is proportionately higher than the weight savings.

Waste-Heat Recovery: The phase-change method of recovering waste heat that is being studied by DOD looks interesting and would be worth following.

Thermoelectric Converters for Waste-Heat Recovery: While offering the potential for energy savings, the cost and weight impact should be determined.

Heat Storage: As above, the cost and weight impact of any proposed system for storing heat for cab climate control during the off cycle would have to be determined.

Several other topics were not recommended for DOE research, either because they are mature or the industry is making satisfactory progress on its own.

Controls: Advances in control technology are being made by the OEMs, as needed. This is not an issue for component manufacturers.

Thermostats: This subject falls within the area of controls.

Electric Drives: This is important but is considered a subset of variable-speed drives. 
Compressors: Compressors tied to the engine with belts or gears are considered mature and not in need of research. Variable-speed electrically driven compressors were included in the first item above.

Sensors: This topic is considered part of controls.

Fan Clutches: This is considered mature technology.

\section{BREAKOUT SESSION D}

\section{Modeling, Simulation, Underhood Airflow, Aerodynamics}

Facilitator: Steve Zoz, Ricardo, Inc.

Recorder: Rich Valentin, Argonne National Laboratory

\section{Participants:}

Sunil Jain, Navistar

Chuck Brown, American Cooling Systems

Ross Sheckler, Dynacs Engineering

Gene Barron, Freightliner

Steve MacDonald, adapco

Rose McCallen, LLNL

Ray Miraflor, AlliedSignal

Jon Wattelet, Modine

Rory Lewis, Flowmaster

Moe Khaleel, PNNL

Rich Couch, LLNL

John Johnson, Michigan Technological U.

\section{Summary:}

It was stated that the overall objective in this general subject area was to predict vehicle fuel economy and emissions for an entire drive cycle. This implies true transient analysis and also assumes that ways to validate the models and simulations are available. As a starting point, a list of possible submodels was given. These included the following: 
- powertrain

- vehicle load prediction

- control systems

- cooling systems

- external aerodynamics
- underhood airflow

- cooling and refrigeration

- lubrication cooling circuit

- cabin airflow

The initial discussion concerned where within this list one should place emphasis and the needed level of detail. There seemed to be consensus that one must start simply and always realize that almost all of the listed topics are, in some sense, coupled effects that will contribute to the eventual goal of predicting economy and emissions.

There was an extensive discussion of what codes are assumed to be needed. Several of the industry people felt that it is sufficient to have a "zero-dimensional" code. That is, a simple collection of point models that are tied together to give overall system behavior and to trade off the effects of variations of design specifications and see how these alter total drive-cycle economics. At the same time, it was realized that many of the important effects cannot be treated in this way - vehicle aerodynamics and underhood cooling being obvious examples. It was noted, however, that the heavy-vehicle industry (at least in the U.S.) is most comfortable with simulation at the PC level rather than using more computer-intensive CFD calculations such as those common in the analysis of automotive systems.

There were a number of unanswered questions concerning the level of simulation detail needed. Following are some examples:

- Are issues of durability to be treated? That is, whether special models are needed to address metal temperatures in engine systems, the effect of temperature cycles on durability and failure rates, and how one would link thermal models to finite-element codes that could analyze structural questions.

- There was no clear way to link the type of thermal analyses being discussed to economic analysis or how these connections may create constraints on alternate system configurations.

- Are we talking about codes that would be used early in a design or as part of the analysis of a completed design? This is of major importance because early in the design, a simple system code would probably be sufficient, while in evaluating a near-final design, a multidimensional treatment would be needed (e.g., to evaluate alternate underhood system configurations and the placement of components). 
- It would be desirable to have all codes or systems of codes use some consistent interface specification so data transfer between codes or code modules would not be a problem. Who would decide such issues and define standards that all OEMs and suppliers could live with?

The discussion shifted to what would be a reasonable first effort by DOE. That is, what would produce tools most useful to the industry? It was suggested that DOE could sponsor work on a nonproprietary code system that all could use. Prior to this, it would be useful, even at the zero-dimensional level, to learn what is available in the open literature and now in common use, what submodels exist at what level of detail, what data are available for code validation, and what models can be borrowed directly from the auto industry. This would show where the holes are and where model development could have the greatest benefit to the industry as a whole. Of particular interest at all levels of detail would be standard experimental data for code validation. Too often, individual designs are modeled with little attention to the expected level of accuracy of the simulation - both because of rough approximations used in the analytical methods and a lack of appreciation of the errors inherent in the validation data itself. A DOE effort to benchmark certain system analyses and subsystem models against the best available data would be of use to all.

It was pointed out that the DOE labs have extensive experience in producing basic data for use in code validation. The national labs have done this sort of work for a number of industries over the years (e.g., basic thermal-hydraulic data for devices such as heat exchangers, steam generators, coal and gas combustion devices, etc.). It would be useful to perform a similar role for areas of interest to the heavy-vehicle industry, e.g., fan performance, radiator heat transfer, refrigeration systems, etc. In addition, the DOE labs have had extensive experience in creating flexible overall system models that are not tied to the limitation of a specific design.

There was extensive discussion of the unique nature of the heavy-vehicle industry and how little control the OEMs often have over the specification of subsystems in their products. Using the requirements specified by a large fleet operator as an example, it was noted that the manufacturer of a Class 7-8 truck may be told what engines to use, what cooling systems are to be installed, etc. Thus, the OEM has much less control over optimization of the total system than, say, an auto manufacturer would have. Also, because individual suppliers are often producing packaged "black-box" subsystems for integration into a final product, a buy-in would be needed from each supplier to have them transfer needed system modeling data to some central location (in some standard format) before any true integrated system model would be possible. 
It was noted that whatever DOE might choose to develop, the real test will be its use by industry. That will be the only test of value. It is DOE's role to try to understand the overall economic needs of the heavy-vehicle industry and to create a program that is useful to that group while, at the same time, increasing fuel efficiency and reducing harmful emissions from the next generation of truck designs - those being DOE's primary goals.

In many of the discussions, it was stated that all of the subsystems of a Class 7-8 truck are interconnected, and this drives the need for a systems code to model such interactions. While this is true to a degree, it is essential to realize that not all parts of the system are closely coupled (e.g., the cab interior air system is only weakly connected to other systems) and, in deciding modeling priorities, it would be valuable to concentrate on closely coupled systems first, e.g., the relationship between underhood cooling simulation and fan modeling.

There were questions of what would drive OEM interest in improved analysis and modeling capability. The best answer seems to be through the possibility of reducing the testing of vehicles. The creation of "virtual vehicles" would allow one to test perhaps only a final product and this could be a true cost savings to manufacturers. There were also questions of why DOE would have an interest in this area and suggestions that perhaps DOE should push for changes in the regulatory climate. That would have greater impact on the overall efficiency of heavy vehicles than support for any technical change that would, at best, create only marginal efficiencies.

There was some discussion of the role of new materials in changing the thermal efficiency of heavy vehicles. While somewhat removed from the main thrust of the session, it was felt that new materials and the simulation of their effect on heat-transport systems was an area deserving consideration. Only the large integrated companies (e.g., CAT) would be interested in this, however, since they are the only ones with a broad enough view to see the impact on a total system basis.

The subject of how compact heat exchangers and new materials could be combined also was discussed. This combination could have a significant effect on new truck designs particularly front-end designs through alterations in both internal air flow and external aerodynamics. In a similar way, improved fans and fan packaging could alter truck design. It was felt that DOE could be of value in developing advanced design methods for fans and in providing the basic flow data needed to validate fan-design methodology.

There is a real need to better understand phase-change systems, both in HVAC packages and in engine heat transfer. This could include nucleate boiling in engine cooling 
passages, the effect of vibration on phase behavior, the generation of wear (pitting) by bubble collapse, etc. This is an area where there could be two major points of focus. For some systems, it would be best to concentrate on prevention of boiling under any operating condition - this would be for trucks similar to those now in service. For the next generation, the control of nucleate boiling through detection sensors and computer control of flow would be a way to produce more efficient systems that could, for short periods of intense loading, operate safety in thermal regimes not now possible.

The group did not come up with a definitive list of recommendations; however, the topics that were considered of interest in the general area of modeling and simulation were the following (not in any priority order):

- Development of a generic (open literature) system code of zero or one dimension.

- Creation of an experimental database on thermal performance of systems and subcomponents that could be used for code validation.

- Study of phase change, boiling, and condensation, in geometries and under conditions typical of heavy-vehicle design. This would provide the basis for both control of boiling and, eventually, for advanced cooling systems.

- Explore by simulation the impact of new materials and new radiator designs on the overall design of trucks and other heavy vehicles.

- Survey the "holes" in current design codes and CFD applications to determine what areas would most profit by advanced simulations.

- Develop a mechanism for rapid interchange of modules of simulation packages so that data can be passed between various levels of modeling without the need for extensive development of interface codes (e.g., direct use of CAD-CAM geometry input in system codes and coupling of thermalanalysis systems with finite-element methods used in structural evaluation).

- Evaluate the methods available within the passenger car industry that could be adapted to heavy vehicles with minor modifications, e.g., use of current CFD codes for underhood airflow augmented by an expansion of heat-transfersimulation capabilities to better handle severe transients and high heat loads. 
Distribution for ANL-00/10

$\underline{\text { Internal }}$

Y. S. Cha

T. M. Mulcahy

K. L. Uherka

H. Drucker

N. T. Obot

M. W. Wambsganss (25)

K. E. Kasza

R. B. Poeppel

D. P. Weber

J. R. Hull (20)

J. A. Stephens (90)

C. A. Malefyt

A. M. Tentner

TIS Files

External

ANL Libraries

ANL-E

ANL-W

Energy Technology Division Review Committee

H. K. Birnbaum, University of Illinois at Urbana-Champaign

I.-W. Chen, University of Pennsylvania

E. M. Logothetis, Ford Motor Co., Dearborn, MI

H. S. Rosenbaum, Fremont, CA

S. L. Sass, Cornell University

R. K. Shah, General Motors Corp., Lockport, NY

S. Smialowska, Ohio State University, Columbus 